\title{
Prufrock-Shmufrock? An Appendage to J. Alfred's Nomenclature
}

\author{
Robert F. Fleissner
}

Is Prufrock's name a mere will-o'-the-wisp? Several lengthy studies of its meaning, etymologically and onomastically (or connotatively), have raised a number of issues concerning what Eliot had in mind, consciously or unconsciously. These have, to some extent, overlapped, and so a study bringing them together is in order. Each segment of the full name deserves careful study again, including the ambiguous initial, the resonant middle name, and the Germanic surname.

At the 1990 dinner of the American Name Society, Michel Grimaud kindly alerted me to the fact that my close examination of "The Love Song of J. Alfred Prufrock," with its initial study of the anti-hero's name ${ }^{1}$ was anticipated in certain respects in an essay of his own some years earlier (1977). Having now examined Grimaud's work, I would like to offer some comments as addenda.

First, notable though his article certainly is as a study of the Prufrockian name, among other matters, ironically the name of his own work "Hermeneutics, Onomastics and Poetics in English and French Literature" provides no hint in advance that two major sections in it concern this very subject. Hence I feel a bit excused for having inadvertently bypassed it. Still, some of the points it makes are notable enough to be worthy of special comment, however belatedly. Let us examine certain of these seriatim. 
Grimaud affirms that 'Prufrock will seek his 'proof' in a 'frock;' that is, he will ask his overwhelming question of a lady" (903). That turn of phrase appears to reflect the most obvious connotation of the surname that I had passed over. Instead, the hint of "frock" had, to my ken, intimated that Prufrock had something rather frock-like about himself, a point also noticed by others and underscored especially in a review of the book of mine which was entirely devoted to this Pierrot-like character (see Johnson 52-53). ${ }^{2}$ True, Grimaud likewise is aware of this suggestiveness, notably when he refers to "the asexual (bisexual?) ambiguity of the word 'frock"n (903). Because he tackles other meanings inherent in the surname at the same time, particularly the hint of touchstone, this one sartorial point could be overplayed, yet it is worthy of careful treatment again just the same. The point is that two attitudes appear to be somewhat at odds with one another: on one hand, the "frock" meaning in normal terms would hint at the speaker's need for some intimacy with the opposite sex; on the other, a plausible androgynous effect might call that into question. In response now, I would grant that Grimaud's original insight would hold, that the persona is indeed in search of "his 'proof' "even" in a 'frock," though it is going perhaps a bit far here to conjure up specific deviancy. To my mind, "asexual" or even, say, homoerotic meaning may also be present (especially if a reflection of Eliot's friend Jean Verdenal is enlisted as well), but I myself would hesitate still to assert "bisexual." For that is too compromising. In other words let us take the question mark after "bisexual" in Grimaud's statement as really calling into question such a reading as well. Eliot, as is so well known, opposed liberal Freudianism, ${ }^{3}$ which would allow for such behavior as subliminal and even normal under certain circumstances. That does not mean that he could not have enjoyed the bisexual in spite of himself, as it were, but it certainly does not prove that.

Along with this subtle distinctiveness, we might further notice how what might be taken instead as the -rock suffix in the speaker's name links somewhat with the German noun Rock, evidently thereby harking back also to the Germanic origins of the firm name Prufrock-Littau in St. Louis, as I and others have pointed 
out elsewhere (even as the "Anglicized" form, Prufcoat, has been located in a more recent St. Louis telephone directory). Incidentally, the allusion onomastically to Lithuania in the combination Prufrock-Littau name provides yet another hint of intertextuality, linking with The Waste Land again. Even as Grimaud has associated, very neatly but quite convincingly to my mind, the second syllables in Alfred Prufrock with the phrase "red rock" (then also repeated) in the longer poem (1. 24-26), ${ }^{4}$ so we are duly reminded that the garrulous lady in Munich being described also at the outset of Eliot's most famous or representative poem refers to her deriving from Lithuania, thereby utilizing the German form again (thus "aus Littauen" but still "echt deutsch"). Further, the German Rock can refer either to a man's jacket (or overcoat) or to a woman's frock. Is not such ambivalence simply part of Prufrock's world? Agreed, etymologically, the sensitive reader may be apt to think, first of all, of the speaker's name as related to that of a specialized tailor (i.e., prüf[en]-Rock, to accommodate two German words). Although an editing assistant for the Peter Lang Press, which was publishing my "Prufrock" book, helpfully submitted this to me, her own Germanic origins aiding in substantiating this verdict, plausibly the more accurate origin of the name would rather reflect the meaning of Prüfstein, which conjures up "touchstone" in German. Grimaud, to be sure, brings in the connotation of this latter meaning as well, although without pointing to Eliot's own interest thereby in the well-known "touchstone theory" of Matthew Arnold, a Victorian critic Eliot much admired. ${ }^{5}$ Clearly resonances of that term emerge in addition.

One especially enlightening aspect of the Grimaud study also bears on the possible Germanic origin, his aperçu that "Alfred" in Old High German meant 'elf counselor,' as any popular name dictionary will reveal" (904). Our only qualm with such a reading may be that he uses it to link Prufrock up with the old counselor in Hamlet, Polonius, for most of the factual evidence overtly points against Eliot's liking, or making use of, this play. As the speaker himself takes pains to assert, such a connection was simply not "meant to be." True, Grimaud qualifies this point neatly by granting that "Prufrock is and is not a counselor" (905), yet the allusion to Ophelia's father seems questionable from the start, 


\section{Names 41.1 (March 1993)}

especially when the "Hamlet" being alluded to may be Laforgue's poetic version only. And Polonius does not appear there. It is all well and good to assert, as Grimaud and some other scholars have, that even though Eliot was to denounce the Danish tragedy as "most certainly an artistic failure," a position which he never really recanted, because its emotions are curiously "in excess of the facts" (in part), Prufrock is himself ironically a hesitant Hamlet type and so deserves similar indictment; but, at any rate, it is hard to believe that that is what Eliot himself would have had in mind. (It is one thing not to take Prufrock too literally, but another to go overboard). In affirming that he was assuredly no modern "Prince Hamlet" and was never intended to be such, Prufrock is hardly then switching simply, let us say, to thoughts of Hamlet's mother and thereby taking upon himself concomitantly the symbolic role of Ophelia "The lady doth protest too much." In any case, to be fair, Grimaud does not appear to make too big an issue of this matter.

In dealing with the initial "J." in the titular figure's name, Grimaud had likewise several sensitive points to convey, ones I had entirely overlooked and which deserve restatement. But the most important aspect, to my mind, is in his duly recognizing, as I did, the possible hint there of Jean Verdenal's Christian name. Yet, at this point, a subtle distinction should be made: the poem itself was not officially dedicated to anyone. Admittedly, all kinds of unofficial dedications may be in the offing (I have inferred elsewhere, for example (ASP 9), that whereas The Waste Land was officially dedicated to Pound, it could still have unofficially been dedicated to Verdenal); still, the important issue here is that only when the monologue appeared in Eliot's collection entitled Prufrock and Other Observations was a dedication apparent, one which the entire work then received. Grimaud does grasp this subtle point (though my reviewer Johnson failed to) by arguing as follows: Why otherwise "have a Dantean epigraph on both the title page and the first page of the poem" (906), that is, why if the dedication in the book did not relate to the major and leading poem in it? Moreover, the title page can be construed, as he says, as "part of the text" itself. These points are clearly sensible.

A further association Grimaud very judiciously makes, though 
quite indirectly, is that the initial "J." can be taken as a special homage to Jean Verdenal notably because his first name "John (like John the Baptist) begins with a 'J."' (906). The point is that the speaker specifically refers to his head being brought in upon a platter, and although John the Baptist is not cited by name (and some question arises about which literary story of Salome is alluded to, Wilde's or Laforgue's), it could only be he. How far this biblical association should otherwise be taken, whether for example the allusion at the end to drowning links somehow with baptism (a horrid idea at first, but one utilized in a prominent novel by Flannery O'Connor (The Violent Bear It Away), and which points obliquely to Yeats's resonant line "the ceremony of innocence is drowned," becomes a moot point, though we readily can compare birth relating to death in the later "Journey of the Magi"). One recent critic, Nathan Cervo, in commenting on Prufrock's truncated desire to emulate John the Baptist, observes that the poem might well be retitled "The Wallflower as the Letter J!" (See Cervo's own title.)

Grimaud admits a number of other connotative significations for the initial "J." which would enter in, though some fidgety readers might ponder how much can validly be built upon a first letter. At one point he even announces that the 'J.' - must... be read... as the not uncommon abbreviation for Judge!" (906). This surprising feature then would link back with the presumed counselor connotation in Alfred, as cited earlier, and does have its suggestive sidelights. The idea is that "one may note that a common (though especially British) way of referring to a justice of the peace is - using Prufrock's initials - to say 'J. P.' (908n). Truly such legalistic resonances appear entirely in keeping with $\mathrm{J}$. Alfred's judicious-seeming character, even in terms of a certain pretentiousness. And yet they need not thereby usher in Polonius in addition.

Another point Grimaud brings out is that 'J.' might evoke (as in the case of Jay Gatsby) a 'jay,' the bird or, by metaphor, the stupid, inexperienced person or impertinent chatterer a jay is supposed to be" (906). The ornithological import here is that it links stylistically with Prufrock's very character, his (and society's) chattering on and on about trivia so much of the time. As 


\section{Names 41.1 (March 1993)}

Grimaud puts it, "One could hardly ask for a more apposite definition of Prufrock's repetitive style" (906).

A further connotation is in the "sense in which the narrator, with his incompleted ' $\mathrm{J}$.' is close to the great artist whose name is rarely pronounced complete: Michelangelo Buonarroti" (907). Because the protagonist is initially linked also with the women who "come and go, / Talking of Michelangelo" several times, even this resonance is not to be dispelled. ${ }^{6}$

If we were now to add any revelatory signification to this buildup of "J." meanings, the only one that may readily come to mind is the rather stylized one that because early English printers considered the " $\mathrm{J}$ " and "l" to be typologically the same letter, which then was "I," Prufrock's antiquated style would somehow point to an egotism which is anticipated already in his beginning nomenclature. To some extent such a reading would be in accord with Grimaud's questioning whether the " $\mathrm{J}$ " truly represents an initial (903). Whereas he considers also the plausibility of simply an abbreviation, by the same token the letter could be thought of as representing the first-person pronoun, albeit one commonly not followed by an end-stop.

In sum, Grimaud has done an excellent job, and I certainly would have made much use of his article from the start had I learned of its hiding place. Other names in Eliot may well come in for subtle treatment in the future because of their own, similar, Dickensian-like possibilities. ${ }^{7}$ Hence should the antihero's name be shrugged off with, say, a nonchalant "Prufrock-Shmufrock"? ${ }^{8}$ Hardly so. 


\section{Prufrock-Schmufrock? 21}

\section{Notes}

1. See "The Weakness of T. S. Eliot's J. Alfred" as incorporated in Names and Their Varieties (223-29), and Ascending the Prufrockian Stair(1-24).

2. She contends that whereas I find Prufrock's full name at one point "becomingly modest" owing to the initialing of his first name, the overall effect of the secretive nature of that initial I then describe as "fairly imposing." True, yet this paradox is actually self-evident in the name and character themselves, adding to their rich, humorous qualities, and hardly means that I am in effect disavowing my own thesis - a reservation that she confesses to (53). Robert Canary (32) points to my finding a resonance of the name of Alfred Lord Tennyson in Prufrock's dubbing himself an "attendent [sic] lord" and contributes an exclamation point in the process, and Johnson likewise concedes that my study "pushes this association further," whereby the verb she uses might suggest my reaching here. Donald Childs (351) feels that my point is misplaced in the book. Whatever the proper verdict, the basic "attendant lord/Lord Tennyson" echo is clearly subsidiary. Moreover, Grimaud makes much more subtle, psycholinguistic associations than this.

3. See Canary, as cited in my T. S. Eliot and the Heritage of Africa (99).

4. He discerns that the phrase "red rock" links Prufrock to "both the religious aspect and thematics of The Waste Land" (904), both of which are then "reminiscent of Prufrock's drowning at the end of the Song." This is a vibrant inference.

5. On this, see Grover Smith's classic study $(12,96,98,140,342)$.

6. Grimaud bases an entire section of his article ("IV: Poetic Communication") on "J." as relating to "Jay" metathesized as "age:" "Psychologically and psycholinguistically reading ' $\mathrm{J}$.' as a metathesis for 'age' is our boldest interpretation yet" (907), if not a misinterpretation, but such a specialized reading is beyond my purview here (and it probably was not within that of Eliot's own conscious deliberations).

7. Robert Crawford, for example, traces Eliot's Sweeney to Dr. F. L. Sweany, who in effect represents "the doctor Prufrock required" (28).

8. For a Yiddish rendition, see Bluestein's "Prufrock-Shmufrock." That wry essay concerns a Yiddish version of the poem, followed by commentary thereon, by Isaac Rosenfeld. We learn that "Rosenfeld and Saul Bellow used to collaborate in translating Eliot into Yiddish" (55). 


\section{Works Cited}

Bluestein, Gene. "Prufrock-Shmufrock." Yiddish 7 (1987): 53-56.

Canary, Robert F. T. S. Eliot: The Poet and His Critics. Chicago: American Lib. Assn., 1982.

Cervo, Nathan. "Stevens' 'The Comedian as the Letter C." Explicator 50 (1992): 228-31.

Childs, Donald J. "Eliot Facts." Rev. of Fleissner's Ascending the Prufrockian Stair. Essays in Criticism 39 (1989): 348-52.

Crawford, Robert. The Savage and the City in the Work of T. S. Eliot. Oxford: Clarendon, 1987.

Fleissner, R. F. Ascending the Prufrockian Stair: Studies in a Dissociated Sensibility. Ser. IV; Eng. Lang. and Lit., Vol. 86. New York: Peter Lang, 1988. 1-24. Cited as APS.

. "Eliot's 'The Love Song of J. Alfred Prufrock." Explicator 48 (1990): 208-10.

. T. S. Eliot and the Heritage of Africa: The Magus and the Moor as Metaphor. Ser. IV; Eng. Lang and Lit., Vol. 143. Peter Lang, 1992.

. “The Weakness of T. S. Eliot's J. Alfred: More of Verdenal in 'Prufrock." Names 38 (1990): 43-48.

Grimaud, Michel. "Hermeneutics, Onomastics and Poetics in English and French Literature." Modern Language Notes 92 (1977): 888-915.

Harder, Kelsie, ed. Names and Their Varieties: A Collection of Essays in Onomastics. Latham, Md: University Press of America, 1986. 223-29.

Johnson, Carol Siri. Rev. of Fleissner's Ascending the Prufrockian Stair. Thalia: Studies in Literary Humor (U of Ottawa) 11 (1990): 52-53.

Smith, Grover. T. S. Eliot's Poetry and Plays: A Study in Sources and Meaning. 2nd ed. University of Chicago Press, 1974. 